\title{
Komparasi Hasil Belajar Siswa Menggunakan Geoboard dan Geopuzzle Pada Materi Segiempat dan Segitiga Kelas VII SMP
}

\author{
Husnul Khotimah ${ }^{1}$, Hernawati ${ }^{2}$ \\ ${ }^{1,2}$ Guru Matematika, MA Subulassalam \\ ${ }^{1}$ husnulkhotimah2424@gmail.com, ${ }^{2}$ ernatherav@gmail.com
}

\section{INFO ARTIKEL}

Riwayat Artikel:

Diterima: 02-08-2018

Disetujui: 19-10-2018

\section{Kata Kunci:}

Geoboard, Geofuzzle, Hasil Belajar, Segitiga, Segiempat

\begin{abstract}
ABSTRAK
Abstrak: Penelitian ini bertujuan untuk mengetahui perbedaan hasil belajar siswa menggunakan geoboard dan geopuzzle pada materi segiempat dan segitiga di kelas VII SMP. Penelitian ini merupakan penelitian eksperimen dengan menggunakan 2 kelas eksperimen yang pada tiap kelas menggunakan alat peraga berbeda. Sampel penelitian diambil dari dua kelas yang terdiri dari 54 siswa dengan menggunakan teknik Simple Random Sampling. Sedangkan instrumen hasil belajar siswa berupa post-test dengan taraf signifikan 5\%. Berdasarkan analisis data, dapat disimpulkan bahwa ada perbedaan hasil belajar siswa yang signifikan antara nilai rata-rata kelas eksperimen 1 dengan menggunakan geoboard sebesar 71,70 dan kelas eksperimen 2 dengan menggunakan geopuzzle sebesar 62,04. Hasil penelitian ini dikuatkan oleh uji-t yang diperoleh t-hitung sebesar 2,26 dan t-tabel sebesar 2,00. Hal ini menunjukkan bahwa terdapat perbedaan hasil belajar siswa menggunakan geoboard dan geopuzzle pada materi segiempat dan segitiga di kelas VII SMP.
\end{abstract}

\begin{abstract}
This study aims to determine the differences in student learning outcomes using Geoboard and Geopuzzle on quadrilateral and triangular material in Senior High School. This research is an experimental research using 2 experimental classes which use different props in each class. The research sample was taken from two classes consisting of 54 students using the Simple Random Sampling technique. While the instrument of student learning outcomes in the form of post-test with a significant level of $5 \%$. Based on data analysis, it can be concluded that there are significant differences in student learning outcomes between the average value of the experimental class 1 using geoboard of 71.70 and experimental class 2 using a geopuzzle of 62.04. The results of this study are corroborated by the $t$-test obtained by $t$-count of 2.26 and $t$-table of 2.00. This shows that there are differences in student learning outcomes using geoboard and geopuzzle on quadrilateral and triangle material in grade 7 of Senior High School
\end{abstract}

\section{A. LATAR BELAKANG}

Belajar secara umum diartikan sebagai perubahan pada individu yang terjadi melalui pengalaman, dan bukan karena pertumbuhan atau perkembangan tubuhnya atau karakteristik seseorang sejak lahir (Trianto, 2014: 18). Belajar merupakan kegiatan yang paling banyak dilakukan orang, belajar dilakukan hampir setiap waktu, kapan saja, misalnya di sekolah, di rumah, di jalan, di dalam bus, di pasar, sedang bekerja, sedang bermain, dan seterusnya. Belajar dapat membawa perubahan bagi si pelaku, baik perubahan pengetahuan, sikap, maupun keterampilan. Dengan perubahan hasil belajar tersebut, membantu orang untuk dapat memecahkan permasalahan dalam hidupnya serta dapat menyesuaikan diri dengan lingkungannya, perubahan-perubahan hasil belajar tersebut dapat berubah ke arah yang positif (Baharuddin, 2010: 161-162).

Berdasarkan observasi peneliti yang telah dilakukan pada tanggal 3 sampai 4 November 2017 di SMPN 5 Sekotong, guru matematika masih menggunakan LKS (Lembar Kerja Siswa) sebagai satu-satunya sumber belajar sehingga siswa cenderung merasa kesulitan dalam proses belajar, baik proses pembelajaran di kelas maupun belajar mandiri, banyak siswa yang mengalami kesulitan dalam mengenali geometri atau bangun datar. Siswa sulit membedakan antara jajar genjang atau trapesium dan jenis-jenis segitiga. Selain itu, fasilitasfasilitas seperti alat peraga masih minim digunakan dalam proses pembelajaran dan guru matematika hanya terpaku mengajar dengan menggunakan LKS 
saja. Sehingga perlu diadakan perbaikan dalam proses pembelajaran baik dalam metode belajar maupun bahan ajar yang digunakan. Dari hasil wawancara dengan guru matematika kelas VII di SMPN 5 Sekotong tanggal 3 sampai 4 November 2017 terdapat beberapa masalah yang ditemukan oleh peneliti yaitu kurangnya pemahaman konsep matematika siswa dan kurangnya minat belajar dan motivasi belajar matematika dikarenakan siswa masih beranggapan bahwa pelajaran matematika adalah pelajaran yang sulit, dan masih kurangnya alat peraga yang mendukung proses pembelajaran. Sehingga dibutuhkan suatu alat peraga dalam mendukung proses pembelajaran. Adanya alat peraga akan mempermudah kinerja guru dalam menerangkan materi pelajaran dan membuat siswa lebih mudah paham terhadap materi tersebut.

Melihat kondisi yang ada maka solusi yang ditawarkan oleh peneliti terhadap permasalah tersebut adalah penggunaaan media pembelajaran yang sesuai dengan materi pelajaran agar media pembelajaran dapat berfungsi dengan baik. Media pembelajaran dapat dibuat sendiri oleh guru sesuai dengan materi sehingga akan lebih kreatif dan menyenangkan bagi siswa. Dimana media pembelajaran seperti alat peraga geoboard (papan berpaku) dan geopuzzle adalah media pembelajaran yang mempermudahkan guru dalam menunjukkan bentuk-bentuk bangun datar sedangkan bagi siswa dapat lebih mudah mengetahui bentuk bangun datar tanpa memerlukan banyak waktu untuk menggambar di kertas, tanpa menggunakan penghapus, penggaris, pensil dan kertas.

Geoboard adalah alat bantu dalam mengajarkan konsep geometri, seperti konsep bangun datar, konsep keliling bangun datar dan menghitung serta menentukan luas sebuah bangun datar (Sundayana dalam Lastrijannah, 2017: 2). Geoboard dikenal juga dengan papan paku yang dibuat dari papan, berbentuk persegi panjang atau bujur sangkar. Pada papan itu dibuat bujur sangkar-bujur sangkar kecil yang pada setiap titik sudutnya ditancapkan paku setengah masuk dan setengah lagi masih timbul.

Media geoboard memiliki banyak keunggulan diantaranya mudah pembuatannya, lebih ekonomis dengan biaya pembuatan yang murah, dan bisa digunakan berkali-kali, alat dan bahan untuk memproduksinya mudah diperoleh, bisa digunakan sebagai media bermain dengan memanfaatkan karet gelang. Adapun kekurangan dari media geoboard, diantaranya lebih banyak menuntut peran guru, media geoboard sangat berbahaya bagi anak karena terdapat paku yang tajam, banyak waktu yang terbuang untuk pembuatannya, dan perlu kesediaan untuk berkorban secara materiil (Lastrijannah, 2017: 3).

Puzzle adalah permainan yang terdiri dari potongan gambar-gambar, kotak-kotak, bangun- bangun, huruf-huruf dan angka-angka yang disusun menjadi sebuah permainan yang memiliki daya tarik. Sehingga permainan puzzle akan membuat peserta didik menjadi termotivasi untuk mengikuti pembelajaran dengan merangkai potongan puzzle secara tepat dan cepat (Srianis, 2014: 5). Mainan puzzle adalah salah satu alat permainan yang sangat menarik untuk anak-anak yang bisa merangsang kemampuan motorik, sensorik, koordinasi dalam berinteraksi, membangun kognitif dan kreatif. Sedangkan geopuzzle merupakan puzzle yang dapat mengembangkan keterampilan mengenali bentuk geometri (segitiga, persegi, dan lain-lain), anak akan berlatih untuk mencocokkan kepingan puzzle geometri sesuai dengan papan puzzlenya ( Kumala, 2015: 3).

Dengan teknik permainan yaitu harus mengelompokkan bentuk kepingan yang sama sebelum merangkai puzzle untuk mempermudah mendapatkan gambar yang utuh. Jadi, sebelum bermain puzzle terlebih dahulu harus mengenal dan mampu membedakan tiap bentuk-bentuk pada kepingan puzzle yang akan dirangkai.

Berdasarkan permasalahan yang telah diuraikan diatas, maka peneliti mengangkat judul "Komparasi Hasil Belajar Siswa Menggunakan Geoboard dan Geopuzzle Pada Pokok Bahasan Segiempat dan Segitiga kelas VII SMPN 5 Sekotong Tahun Ajaran 2017/2018".

\section{B. METODE PENELITIAN}

\section{Rancangan Penelitian}

Penelitian ini termasuk penelitian eksperimen yang melibatkan dua kelompok, yaitu satu kelompok sebagai kelas eksperimen 1 dan satu kelompok sebagai kelas eksperimen 2. Kelas VIIB (Eksperimen 1) sebanyak 27 siswa diajarkan menggunakan media pembelajaran geoboard, sedangkan kelas VIIC (Eksperimen 2) sebanyak 27 siswa diajarkan menggunakan media pembelajaran geopuzzle. Adapun desain penelitian ini menggunakan Post-test Only Control Group Design yang modelnya dapat digambar sebagai berikut:

TABEL 1

\begin{tabular}{ccc}
\multicolumn{3}{c}{ POST-TEST ONLY CONTROL GROUP DESIGN } \\
\hline Kelas & Perlakuan & Post-test \\
\hline Kelas VII B (Eksperimen 1) & Geoboard & Ya \\
\hline Kelas VII C (Eksperimen 2) & Geopuzzle & Ya \\
\hline
\end{tabular}

\section{Sumber Data}

Sumber data dalam penelitian ini ada dua macam, yaitu: (a) Tes hasil belajar, digunakan untuk mengevaluasi hasil belajar siswa setelah proses pembelajaran. Evaluasi dilakukan pada kelas eksperimen 1 dan kelas eksperimen 2. Adapun data yang diambil dari kedua kelas ini berupa nilai tes akhir (posstest) sesuai dengan rancangan penelitian yang digunakan; dan (2) Dokumentasi, dalam 
pengumpulan dokumentasi, peneliti menyelidiki benda-benda tertulis seperti daftar hadir siswa.

TABEL 2

KISI-KISI TES HASIL BELAJAR SISWA KELAS VII SMP PADA MATERI SEGITIGA DAN SEGIEMPAT

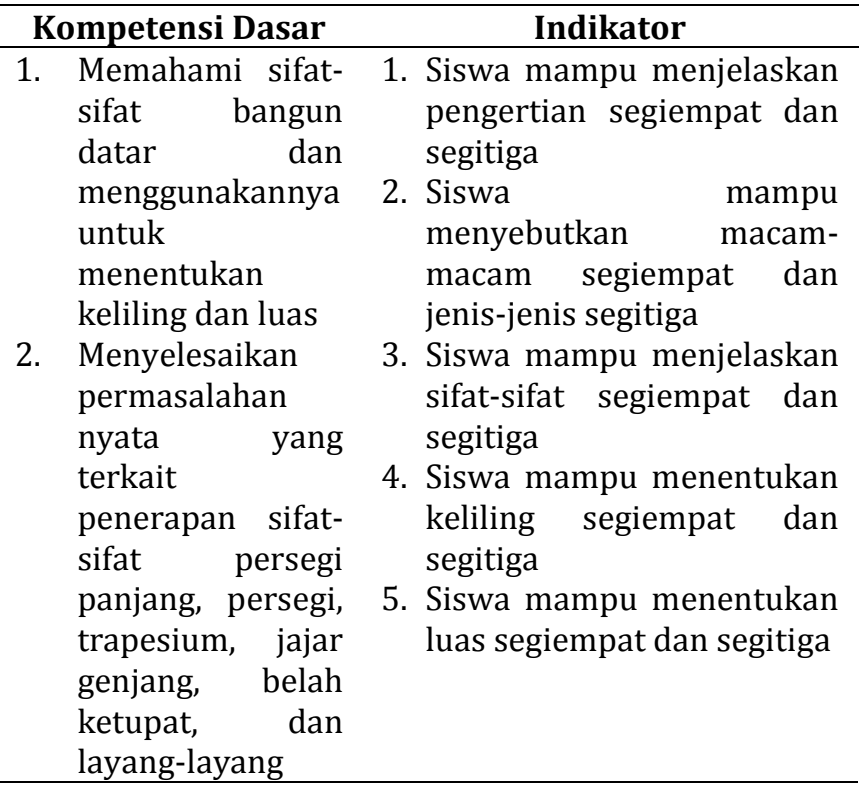

\section{Tahap Pelaksanaan}

Pelaksanaan pengajaran yang dilakukan penelitiyaitu selama empat kali pertemuan pada kelas eksperimen 1 dan kelas eksperimen 2 . Pelaksanaan eksperimen dilaksanakan sebagai berikut:

a. Memberikan perlakuan (treatment) pada kelas eksperimen 1 dan kelas eksperimen 2. Kelas eksperimen 1 menggunakan media pembelajaran geoboard atau papan berpaku sedangkan kelas eksperimen 2 menggunakan media pembelajaran geopuzzle.

b. Memberikan post-test pada kelas eksperimen 1 dan kelas eksperimen 2 yang telah diberikan perlakuan (treatment).

c. Mengumpulkan data kasar

d. Mengorganisasikan data sesuai dengan variabel yang telah ditentukan

e. Menganalisis data dan melakukan tes signifikan dengan teknik statistika yang relevan untuk menentukan tahap signifikan hasilnya

f. Membuat kesimpulan

\section{Analisis data}

Uji hipotesis akhir bertujuan untuk mengetahui tingkat kemampuan siswa. hasil yang diharapkan dari uji hipotesis akhir adalah adanya perbandingan hasil belajar siswa kelas eksperimen 1 dan kelas eksperimen 2. Berdasarkan hipotesis yang diajukan, uji hipotesis yang akan digunakan adalah uji statistik $\mathrm{t}$, dengan formula:

$$
t_{\text {hitung }}=\frac{\bar{x}_{1}-\bar{x}_{2}}{\sqrt{\frac{\left(n_{1}-n_{2}\right) s_{1}^{2}+\left(n_{2}-1\right) s_{2}^{2}}{n_{1}+n_{2}-2}\left(\frac{1}{n_{1}}+\frac{1}{n_{2}}\right)}}
$$

Dengan ketentuan: $\bar{x}_{1}=$ nilai rata-rata kelas VIIB (Eksperimen 1); $\bar{x}_{2}=$ nilai rata-rata kelas VIIC (Eksperimen 2); $\mathrm{n}_{1}=$ jumlah sampel kelas VIIB (Eksperimen 1); $\mathrm{n}_{2}=$ jumlah sampel kelas VIIC (Eksperimen 2); $\mathrm{s}_{1}=$ varians data kelas VIIB (Eksperimen 1); $s_{2}=$ varians data kelas VIIC (Eksperimen 2). Sedangkan keputusan hasil uji statistic, digunakan ketentuan Jika $t_{\text {hitung }}>t_{\text {tabel, }}$, maka $\mathrm{H}_{0}$ ditolak dan $\mathrm{H}_{1}$ diterima artinya, terdapat perbedaan hasil belajar siswa menggunakan geoboard dan geopuzzle pada pokok bahasan segiempat dan segitiga kelas VII SMP, begitu juga sebaliknya.

\section{HASIL DAN PEMBAHASAN}

\section{Data Hasil Tes}

Data posttest diperoleh dari hasil tes siswa sesudah diberikan perlakuan. Deskripsi data hasil posttest kelas eksperimen 1 dan kelas eksperimen 2 dapat dilihat pada Tabel 3 berikut.

\section{TABEL 3}

DESKRIPSI DATA POSTTEST BERDASARKAN KELAS

\begin{tabular}{cccc}
\hline Kelas & $\begin{array}{c}\text { Nilai } \\
\text { Tertinggi }\end{array}$ & $\begin{array}{c}\text { Nilai } \\
\text { Terendah }\end{array}$ & Rerata \\
\hline Eksperimen 1 & 100 & 41 & 71,70 \\
\hline Eksperimen 2 & 100 & 40 & 62,04 \\
\hline
\end{tabular}

\section{Uji Hipotesis (Uji t)}

Hasil perhitungan yang telah dilakukan pada uji homogenitas dan uji normalitas yang memperlihatkan bahwa data hasil belajar siswa untuk kedua kelas berdisribusi yang sama (homogen) dan normal. Sehingga, pengujian dapat diteruskan pada analisis data selanjutnya yaitu uji hipotesis dengan menggunakan uji-t. Hasil analisis dapat dilihat pada tabel berikut.

TABEL 4

UJI-T DATA POST-TEST

\begin{tabular}{|c|c|c|c|c|}
\hline Kelas & $\mathbf{N}$ & $\mathbf{t}_{\text {hitung }}$ & $\mathbf{t}_{\text {tabel }}$ & Keterangan \\
\hline Eksperimen 1 & 27 & \multirow{2}{*}{2,26} & 2,00 & \multirow{2}{*}{$\mathrm{H}_{1}$ Diterima } \\
\hline Eksperimen 2 & 27 & 2, & \\
\hline
\end{tabular}

Berdasarkan Tabel $4 \mathrm{di}$ atas, pada $\mathrm{dk}=52$ dan taraf signifikan $5 \%$ diperoleh $t_{\text {hitung }}=2,26>t_{\text {tabel }}=2,00$ maka $\mathrm{H}_{0}$ ditolak dan $\mathrm{H}_{1}$ diterima artinya "Terdapat perbedaan hasil belajar siswa menggunakan geoboard dan geopuzzle pada pokok bahasan segiempat dan segitiga kelas VII SMP Negeri 5 Sekotong".

Penelitian ini bertujuan untuk melihat perbedaan hasil belajar siswa dengan menerapkan geoboard dan geopuzzle sebagai alat peraga pada pokok bahasan segiempat dan segitiga kelas VII SMP 
Negeri 5 Sekotong. Penelitian ini dilaksanakan dengan menggunakan 2 kelas eksperimen. Pada kelas eksperimen 1 yaitu kelas VII B digunakan alat peraga geoboard dan kelas eksperimen 2 yaitu kelas VII C digunakan alat peraga geopuzzle.

Instrumen yang digunakan dalam penelitian ini berupa soal essay yang berjumlah 12 soal. Dimana semua soal yang diberikan kepada siswa dinyatakan valid dan reliabel dengan taraf signifikan $5 \%$ dan $r_{\text {tabel }}$ $=0,381$.

Berdasarkan Tabel 3 Deskripsi data posttest berdasarkan kelas diperoleh nilai rata-rata pada kelas eksperimen 1 adalah 71,70 dan pada kelas eksperimen 2 adalah 62,04, dimana pada kelas eksperimen ini siswa menggunakan alat peraga geoboard sedangkan kelas eksperimen 2 menggunakan alat peraga geopuzzle. Dalam proses pembelajaran, geoboard dan geopuzzle digunakan untuk membantu siswa dalam menerjemahkan soal, tetapi kekurangannya geoboard dan geopuzzle belum digunakan sebagai alat bantu dalam menurunkan konsep segiempat dan segitiga. Dari respon siswa dalam proses pembelajaran, siswa terbantu dengan penggunaan geoboard dan geopuzzle dalam menggambarkan bentuk segiempat dan segitiga. Model pembelajaran kooperatif tipe STAD berbantu geoboard dan geopuzzle cukup dapat meningkatkan hasil belajar siswa dan mampu meningkatkan aktivititas karena siswa bekerja dalam kelompok kecil dalam menyelesaikan masalah segiempat dan segitiga.

Dari hasil uji hipotesis yang telah dilakukan diperoleh $t_{\text {hitung }}=2,26$ dan $t_{\text {tabel }}=2,00$. Karena $t_{\text {hitung }}>$ $t_{\text {tabel }}(2,26>2,00)$ maka $H_{0}$ ditolak sedangkan $H_{1}$ diterima yang artinya ada perbedaan hasil belajar siswa menggunakan geoboard dan geopuzzle pada pokok bahasan segiempat dan segitiga kelas VII SMP Negeri 5 Sekotong.

Dari uraian di atas dapat disimpulkan bahwa pembelajaran dengan menggunakan alat peraga dapat membantu guru dan siswa dalam proses pembelajaran. Hasil dari analisis data yaitu nilai ratarata post-test kelas eksperimen 1 lebih besar dari kelas eksperimen 2 sehingga menyebabkan adanya suatu perbedaan hasil belajar siswa menggunakan geoboard dan geopuzzle pada pokok bahasan segiempat dan segitiga. Jika merujuk pada nilai ratarata geoboard lebih baik dari geopuzzle.

\section{SIMPULAN DAN SARAN}

Berdasarkan hasil penelitian dan pembahasan penelitian memperoleh kesimpulan bahwa kelas eksperimen 1 dengan menggunakan alat peraga geoboard memiliki nilai rata-rata lebih besar dari pada kelas eksperimen 2 yang menggunakan alat peraga geopuzzle. Selain itu pada saat proses pembelajaran menggunakan alat peraga geoboard pada kelas eksperimen 1 diperoleh hasil belajar siswa memiliki rata-rata 71,70 sedangkan eksperimen 2 diperoleh rata-rata 62,04. Selanjutnya dari hasil uji-t diperoleh $t_{\text {hitung yaitu }} 2,26$ dan $t_{\text {tabel }}$ yaitu 2,00 yang berarti bahwa terdapat perbedaan hasil belajar siswa menggunakan geoboard dan geopuzzle pada pokok bahasan segiempat dan segitiga kelas VII SMP Negeri 5 Sekotong.

Berdasarkan penelitian tersebut, tim peneliti dapat menyampaikan saran, yakni: (a) Bagi guru, Guru hendaknya dalam proses pembelajaran menyediakan alat peraga yang lebih banyak untuk memfasilitasi siswa dalam menyelesaikan permasalahan segiempat; (b) Bagi siswa, Dalam pembentukan kelompok guru harus tegas dalam pemilihan anggota kelompok dan memberi aturan dalam pengerjaan LLS; dan (3) Bagi peneliti selanjutnya, Untuk peneliti selanjutnya dapat memanfaatkan geoboard dan geopuzzle dalam menurunkan sifat-sifat dari segiempat bahkan dapat digunakan untuk menurunkan konsep luas dan keliling dari segiempat.

\section{UCAPAN TERIMA KASIH}

Tim Peneliti mengucapkan terima kasih kepada pihak SMP Negeri 5 Sekotong yang telah banyak membantu selama penelitian ini berlangsung, terutama guru matematika dan siswa kelas VII yang sudah mengikuti pembelajaran dengan baik.

\section{REFERENSI}

[1] Ahmadi, Rulam. (2016). Pengantar Pendidikan: Asas \& Filsafat Pendidikan. Yogyakarta: Ar-Ruzz Media

[2] Apriani, Rini \& Eka Megawati. (2012). Intisari Matematika untuk SMP Kelas VII, VIII, dan IX. Bandung: CV Pustaka Setia.

[3] Arikunto, Suharsimi. (2013). Manajemen Penelitian. Jakarta: Rineka Cipta

[4] Asra, Abuzar dkk. (2015). Metode Penelitian Servei. Bogor: In Media

[5] Baharudin. (2010). Pendidikan dan Psikologi Perkembangan. Jogjakarta: Ar-Ruzz Media

[6] Budiyono. (2016). Statistika Untuk Penelitian Edisi ke2. Surakarta: UNS Press

[7] Ismadi, Janu \& M. Andy Rudhito. (2012). Gema Matematika. Jakarta: PT Perca

[8] Kariadinata, Rahayu \& Maman Abdurahman. (2012). Dasar-dasar Statistik Pendidikan. Bandung: Pustaka Setia

[9] Kumala, Lina. (2015). Pengaruh Penggunaan Media Puzzle Lipat Terhadap Hasil Belajar Jaring-jaring Kubus Tema Cita-cita di Sekolah Dasar. Jurnal Pendidikan, 3(2).

[10] Lastrijanah dkk. (2017). Pengaruh Media Pembelajaran Geoboard Terhadap Hasil Belajar Siswa. Jurnal Pendidikan, 4(2).

[11] Nisa', Titin Faridatul dkk. (2015). Efektifitas Penggunaan Geoboard Bangun Datar dalam Pembelajaran Matematika. Jurnal Pendidikan, 1(2).

[12] Slavin, Robert E. (2016). Cooperative Learning: Teori, Riset dan Pratik. London: Nusa Media 
[13] Siregar, Syofian. (2013). Metode Penelitian Kuantitatif Dilengkapi dengan Perbandingan Perhitungan Manual dan SPSS. Jakarta: Kencana

[14] Srianis, Komang dkk, (2014). Penerapan Metode Bermain Puzzle Geometri untuk Meningkatkan Perkembangan Kognitif Anak dalam Mengenal Bentuk. Jurnal Pendidikan, 2(1).

[15] Sugiyono. (2017). Statistika untuk Penelitian. Bandung: Alfabeta

[16] Trianto, Titik Triwulan T. (2014). Mendesain Model Pembelajaran Inovatif, Progresif, dan Kontekstual. Jakarta: Prenadamedia Group

[17] Yusuf, Muri. (2014). Metode Penelitian Kuantitatif, Kualitatif \& Penelitian Gabungan. Jakarta: Prenadamedia Group 